Article

\title{
Wave Energy Assessment along Sicilian Coastline, Based on DEIM Point Absorber
}

\author{
Vincenzo Franzitta *, Pietro Catrini and Domenico Curto \\ Department of Energy, Information Engineering and Mathematical Models, University of Palermo (UNIPA), \\ 90128 Palermo, Italy; pietro.catrini@unipa.it (P.C.); domenico.curto@unipa.it (D.C.) \\ * Correspondence: franzitta@dream.unipa.it; Tel.: +39-091-2386-1941 \\ Academic Editor: Francesco Calise \\ Received: 31 December 2016; Accepted: 13 March 2017; Published: 16 March 2017
}

\begin{abstract}
The use of renewable energy sources is one of the most relevant goals to be achieved in order to match the climate protection targets. As a case study, the paper shows the current electrical energy production by sources in the Sicilian context. Among the renewable energy sources, the paper investigates the wave energy potential along the Sicilian coasts, because of the favorable climate around the island. A point absorber is present in order to exploit this source. Two scenarios are presented, with two different levels of energy production.
\end{abstract}

Keywords: renewable energy; sea wave energy; point absorber; offshore photovoltaic; Sicily

\section{Introduction}

The combustion of fossil fuels has played a dominating role in the building up of greenhouse gases (GHG) in the atmosphere. It is estimated that the energy sector accounts for about two-thirds of all the anthropogenic GHG emissions. About $80 \%$ of the world's total use of energy is based on fossil fuels, and they play an important role in the transport and stationary energy sectors, including electric power generation [1].

Even though conventional sources-such as oil, natural gas, and coal-meet most of the energy demand at the moment [2], renewable energy sources can contribute to energy supply by supporting energy conservation and greenhouse gas reduction strategy [3]. The increasing concerns for the global environmental effects of greenhouse emissions, resulting from energy consumption, make relevant the current role of renewable sources in a regional policy context [4,5]; local authorities are called to play a remarkable role with strategies improving the energy efficiency and sustainability in all energetic uses [6,7] and replacing, as possible, fossil-based technology with proper renewable energy technologies [8,9].

Among renewable sources, wave energy represents a promising sources for those countries characterized by favorable sea wave climate and large coastline extension [10,11]. It is also apparent how this source will be able to exploit areas which are not used nowadays, at the same time creating important supply chain and local job opportunities [12].

The exploitation of sea wave energy will undergo a significant growth in the next decades as soon as the wave energy converter (WEC) technology becomes more mature $[13,14]$. The WEC technology is believed to be at a crucial stage of its development, and research is focused on finding out feasible techno-economic solutions [15]. Such conditions pose serious engineering challenges to the design and deployment of WECs [16], increasing costs of development, production, installation, maintenance, and insurance.

The interest for wave energy is widespread throughout almost all the world, as witnessed by many studies and projects reported in the literature [17]. Currently, there are two different streams 
of research: the first one is focused on the designing and development of WECs; the second one is focused on the evaluation of sea wave parameters and energy potential, in order to identify areas which are more suitable for the installation of WECs. These studies are generally based on mathematical models $[18,19]$, which correlate sea wave motion to wind source; sometimes, measuring-buoys are installed in situ, to validate the previous estimation of sea wave source [20].

Most WECs are currently at the prototypal stage, and only a few of them have been tested extensively in open sea [18]; some examples are: Pelamis, Wave Dragon, Limpet, and Power Buoy [17]. As regards the working principle of these energy converters, it is possible to distinguish: oscillating water column (OWC), oscillating bodies (OBs), and overtopping system (OS). In OWC, the wave motion is conveyed in special air chambers, causing compression and decompression of air reserve, which is forced to flow through the Wells turbines, producing electrical power; the camber can be fixed inside an on-shore structure (for example, Limpet) or installed in a floating buoy (Spar Buoy) [21]. In the $\mathrm{OB}$, the wave motion is picked up by floating buoys that transfer the movement to special energetic converter, based on different solutions (hydraulic pumps, pistons, or linear generators). Finally, the OSs are based on floating docks that are refilled by waves, and particularly the water stored in the reservoir is spilled by hydraulic turbines, producing electrical energy [21].

Obviously, electrical energy production from sea waves will be really feasible only with extensive studies about wave energy potential in the interested areas, a detailed knowledge of energy occurrence, its temporal and spatial variability, and its distribution among different sea states [22].

In scientific literature, several papers focus on the evaluation of sea wave energy potential in the Mediterranean Sea [23]: indeed, in calmer and semi-closed seas, such as the Mediterranean Sea, many technical issues related to extreme sea climate could be more easily solved, making wave energy production still economically viable [24]. Particularly, Iglesias and Carballo [25] evaluated the energy potential along Spanish coasts, Guillou and Chapalain [26] along French coasts, and Vicinanza et al. along Italian coasts [27].

As regards Italy, the measuring wave buoys of "Rete Ondametrica Nazionale" (RON) (i.e., the Italian Government wave buoy network) had a really important role in describing wave climate along the several thousand kilometers of exploitable coastline, measuring all the main parameters that characterize wave climate. Therefore, thanks to the large amount of information taken from these measuring stations, wave atlases along the Italian coastline are now valuable, in which the values of wave power and the average wave energy offshore are exposed $[27,28]$.

Wave energy resource is strongly connected to the bathymetry: a greater water depth increases wave potential due to the lower friction losses, and so all wave buoys are usually located offshore, several kilometers from the coastline; in this sense, Monteforte et al. [29] used a spectral model "SWAN" (Simulating WAve Nearshore) to simulate the propagation of waves along the Sicilian coasts, taking into account the bathymetry of seabed. Moreover, fetch represents an important characteristic too, because it is the distance in which the wind is able to blow: a large fetch should be preferred, because it often defines a more intense and regular wave climate [30].

Some preliminary evaluations of the wave energy potential in Italy have already been assessed in [22,31]; particularly, the Sardinia northwest coast is identified as a "hot spot" (i.e., a site with concentrated wave energy availability) with an average sea wave energy power higher than $10 \mathrm{~kW} / \mathrm{m}$ [32]. As regards Sicily, instead, wave energy power ranges between 6 and $9 \mathrm{~kW} / \mathrm{m}$ in the east and south coast of Sicily [33].

This paper focuses on wave energy production along Sicilian coastline in order to assess how this source might contribute to the reduction of regional fossil fuel consumption and $\mathrm{CO}_{2}$ emissions; with this aim, an innovative WEC for a useful exploitation is designed and developed at the laboratory of Department of Energy and Information Engineering and Mathematical models (DEIM) of the University of Palermo, Palermo, Italy; as will be shown in the next section, this device is conceived to exploit, at the same time, wave and solar energy availability. 
The paper is structured as follows: in Section 2, data on electrical energy consumption and production in Sicily are shown; particular attention is paid to the contribution of renewable energy sources to overall energy production in 2015 and in the previous decade. In Section 3, the sea wave climate around the Sicily is described; an innovative WEC, able to use also a photovoltaic source, is described. A preliminary assessment of yearly electrical energy production and $\mathrm{CO}_{2}$ emissions reduction is carried out.

\section{Energy Consumption and Renewable Energy Sources in Sicily}

Figure 1, obtained through the data provided by [34], presents the evolution of regional electric power plants in the decade 2004-2014; it is important to note that the incidence of renewable capacity was negligible in 2004, while it accounted for nearly 3 GW in 2014, as a result of a subsidizing system during this decade [35].

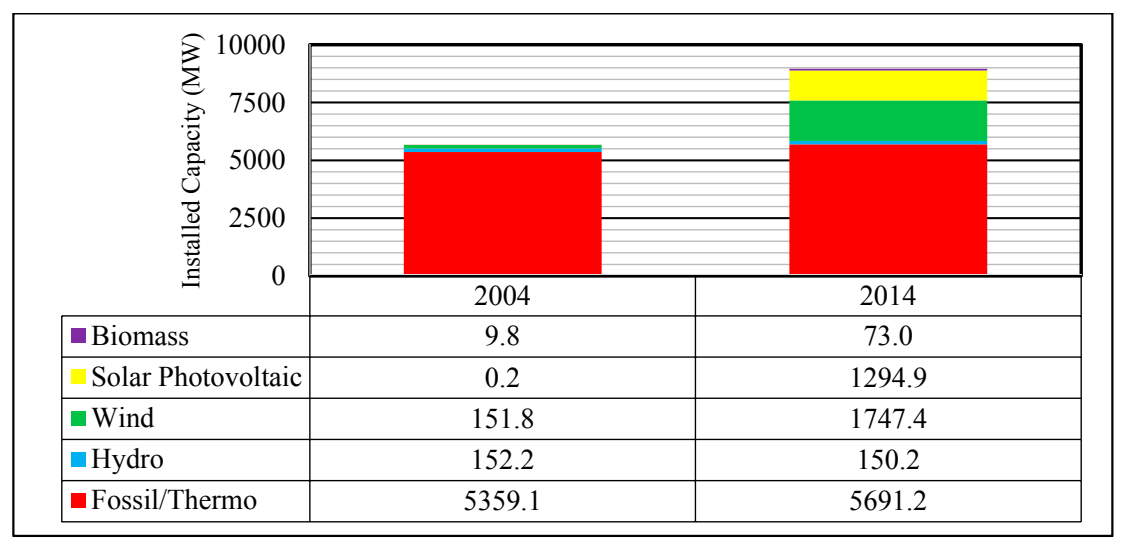

Figure 1. Electrical installed power in Sicily. Comparison during the period 2004-2014.

In 2015, the gross electricity production was equal to 22.87 TWh; as can be seen in Figure 2, the renewable sources accounted only for $21 \%$ of electricity production in 2015 , and solar and wind contributed to $62 \%$ of renewable production; this is very different from 2004 , where only $4 \%$ of total electric production came from renewables and, furthermore, hydroelectric was the predominant source exploited in the region at that time. Figure 2 shows also the comparison of electrical mix sources used in Sicily and in Italy, during 2015. As shown in the graph, the wind source is more used in Sicily (11\%) than in Italy $(5 \%)$ while the photovoltaic source has the same incidence $(8 \%)$. The hydroelectric source is very limited in Sicily, and for this reason it has a marginal importance $(2 \%)$, in comparison to Italy (17\%). Finally, the geothermal sources are not exploited in Sicily [36].
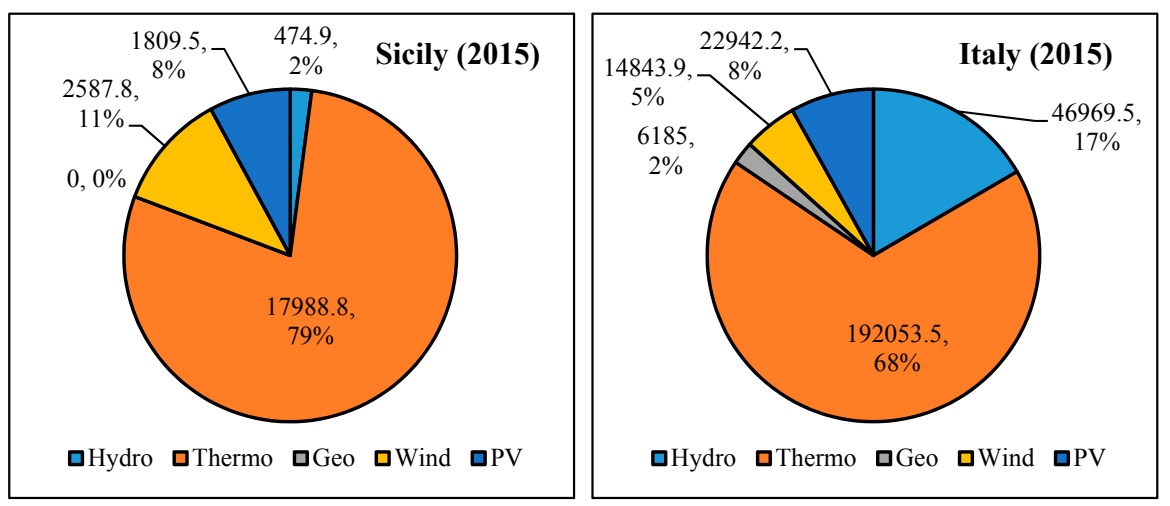

Figure 2. Comparison of gross electricity production (GWh) in 2015 by sources in Sicily and Italy. (Sources: Hydroelectric, Thermoelectric, Geothermal energy, Wind and Solar Photovoltaic). 
It is evident how the policies aimed to subsidize renewable energies have given great impulse to their spread during this decade. Figure 3 shows the installed power and the number of working plants, powered by renewable sources (hydroelectric, wind, photovoltaic, and biomass), during the period 2004-2014. Unlike hydroelectric source that is practically stable over the years, other renewable sources have seen significant increase of installed power and number of plants. In particular, the picture shows the effects of five feed-in schemes "Conto Energia" for photovoltaic plant (the first started in 2006 and the last ceased in 2013). This public funding has generated an explosion of solar energy in the island, where the plant number has grown by different orders of magnitude. Also, wind source shows a remarkable growth during the same period.

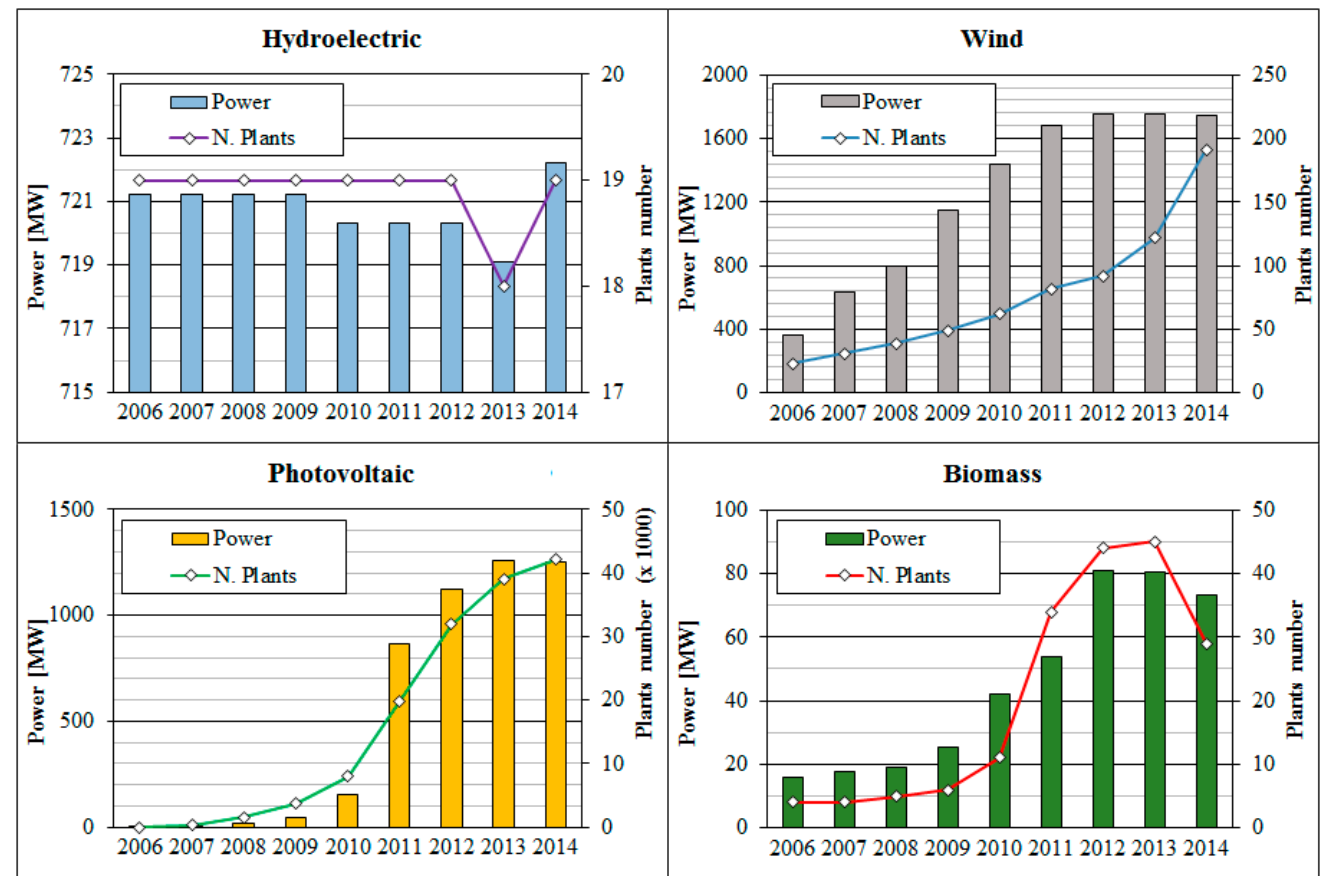

Figure 3. Installed power and plants number from renewable sources (hydroelectric, wind, photovoltaic, and biomass) in decade 2004-2014.

Figure 4 shows the electrical energy production by renewable sources in Sicily during the decade 2004-2014. Wind and photovoltaic are currently the predominant renewable sources in Sicily for electrical energy.

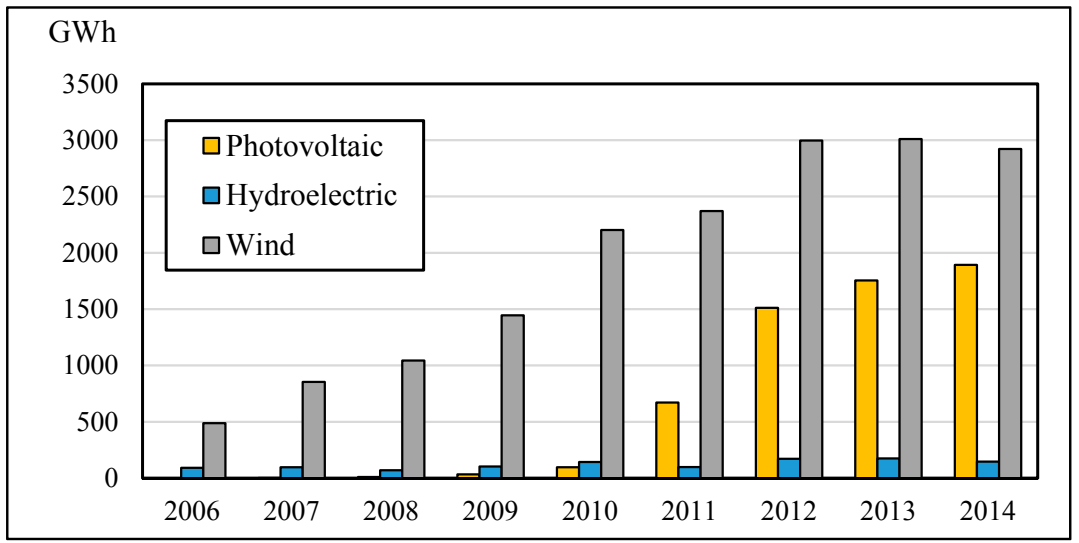

Figure 4. Electrical energy production by renewable sources in Sicily in decade 2004-2014. 
Figure 5 shows the electrical energy consumes in 2015, subdivided for Sicilian provinces and energy sectors. The electrical energy demand of the agriculture sector is very limited. The energy consumption by industries is unevenly subdivided in the region: in fact, the industries are concentrated in Syracuse, Messina, and Catania.

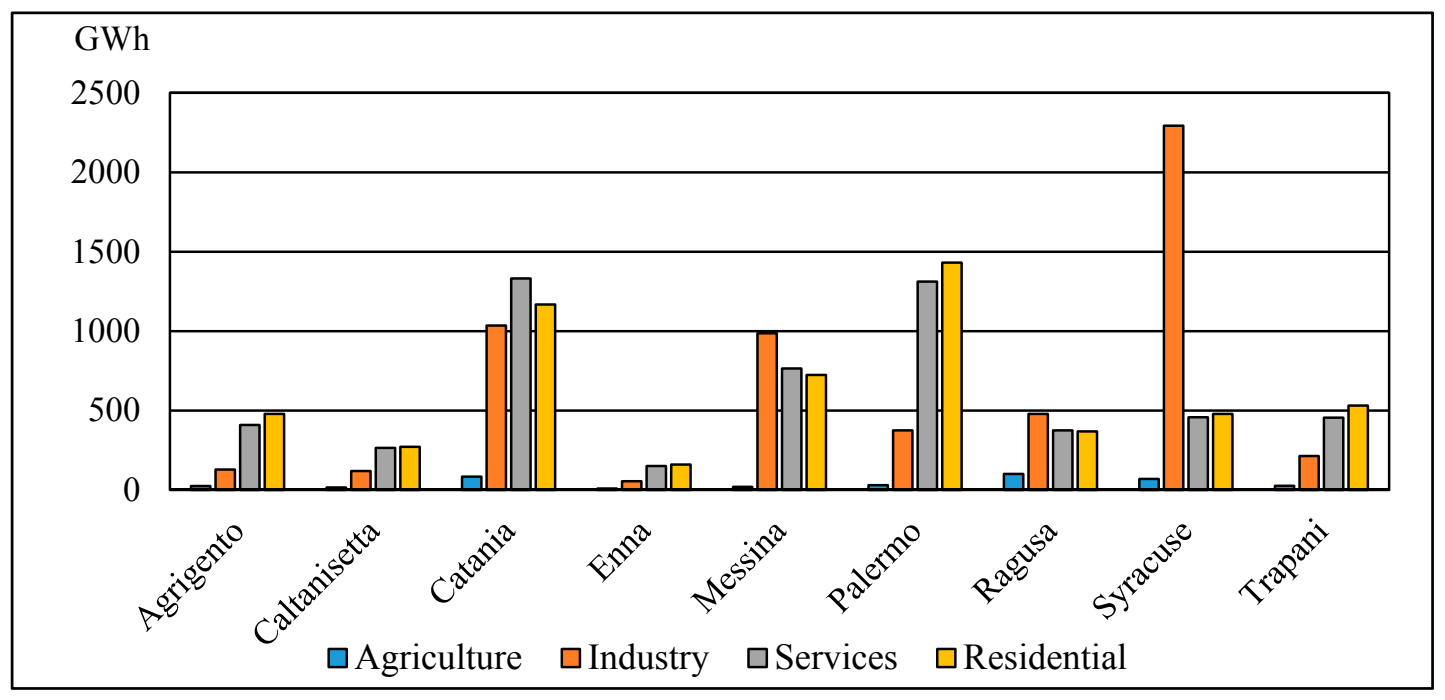

Figure 5. Electrical energy consumes by sectors and provinces in Sicily, during 2015.

Finally, Figure 6 shows a comparison between energy consumes by sectors in Sicily and in Italy, during 2015. As shown in the previous graph, the agriculture sector is very marginal (only $2 \%$ of total electrical consumes in Sicily and in Italy). The electrical consumes in services take the same role in Sicily and in Italy (respectively 32\% and 33\%). The substantial difference is related to residential and industrial sectors. Due to different climate, type of buildings, and heat and cooling systems used for air conditioning, in Sicily the residential sector statistically requires more electrical energy ( $33 \%$ against $23 \%$ in Italy). The less energy consumption in the industrial sector is linked to the limited presence of industrial companies in the Sicilian region, compared to the rest of Italy.

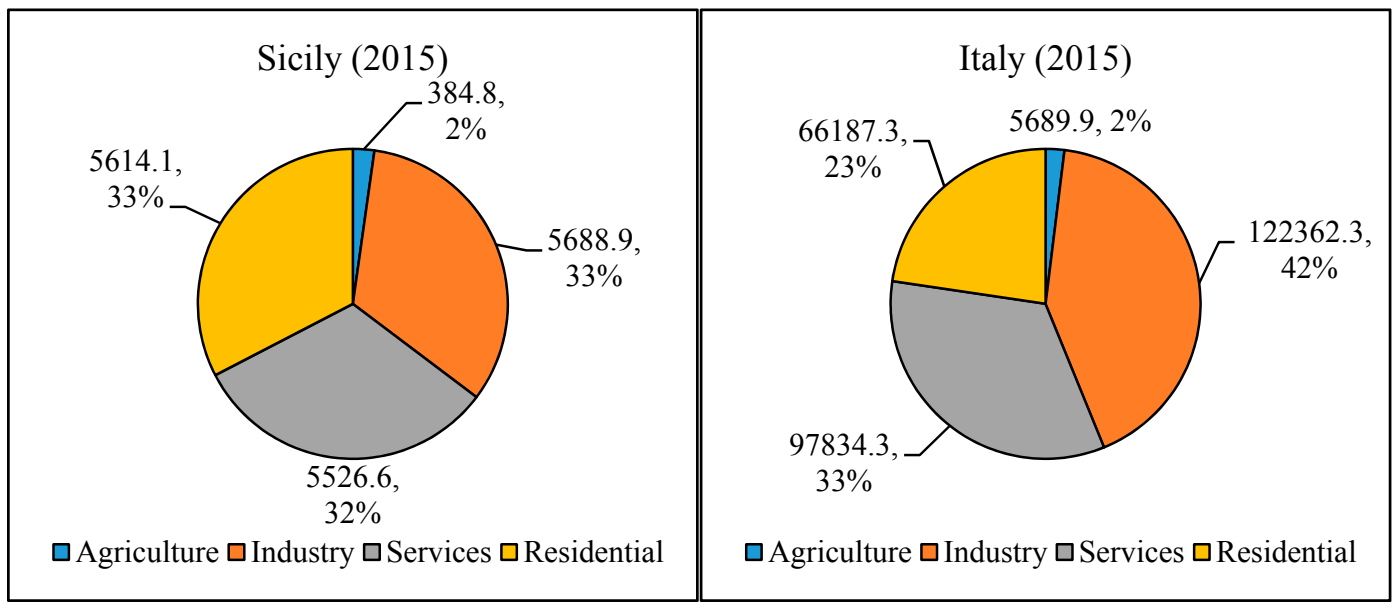

Figure 6. Comparison of electrical energy consumes by sectors in Sicily and Italy, during 2015.

Considering a $\mathrm{CO}_{2}$ emission factor for electric generation park equals to $0.62 \mathrm{t} / \mathrm{MWh}$ [37] and a conversion factor electric/primary energy equals to $0.187 \times 10^{-3}$ tep $/ \mathrm{kWh}$ [38], the part of gross electricity production in 2014 coming from renewables (i.e., nearly $5.5 \mathrm{TWh}$ ) permitted a primary energy saving of $1.03 \mathrm{ktep}$ and avoided the emission of $3.41 \mathrm{ktCO}_{2}$. 
According to regional studies on energy planning carried out in 2007 [39], there is a great potential from renewable sources in Sicily; particularly interesting are the electric exploitations of wind and sun as shown in Table 1. Comparing these numbers with the current use of photovoltaic solar and wind in Sicily, it is easy to understand that only a small part of these potentials has been used during this decade. Future changes will depend on the subsidizing systems adopted by local and national authorities and, obviously, by the improvement of technologies.

Table 1. Renewable potentials in Sicily.

\begin{tabular}{cccc}
\hline Renewable Source & Power (MW) & Annual Electricity Saving $(\mathrm{GWh} /$ Year) & $\mathbf{C O}_{\mathbf{2}}$ Avoided $\left(\mathbf{k t} \mathbf{C O}_{\mathbf{2}}\right)$ \\
\hline Photovoltaic & 4500 & 7100 & 5985 \\
Wind & 10,345 & 24,710 & 16,900 \\
\hline
\end{tabular}

\section{Sea Wave and Offshore Photovoltaic Energy Conversion Assessment}

An in-depth analysis of the wave energy potential along the Sicilian coast was performed using data acquired by sea wave buoys such as a third-generation ocean wave model. Particularly, the potential wave map was obtained thanks to the large amount of data that came from the wave-measuring buoys of the RON. In 1989, it was originally composed by 8 pitch-roll buoys, but in 2007 the total number of wave buoys was of 15 . These buoys are able to record different parameters, such as significant wave height $H_{s}$ (measured in meters), peak period $T_{p}$ (measured in seconds), and average wave direction $\delta_{m}$. At first, recording period was about $3 \mathrm{~h}$, then (with the replacement of all the wave buoys with more technological ones) it was about every $30 \mathrm{~min}$ [40]. In this way, RON was able to describe wave climate with a higher time resolution (but the spatial resolution still remained low).

Figure 7 shows the three different measuring stations of RON, installed in Sicily: Catania, Palermo, and Mazara del Vallo.

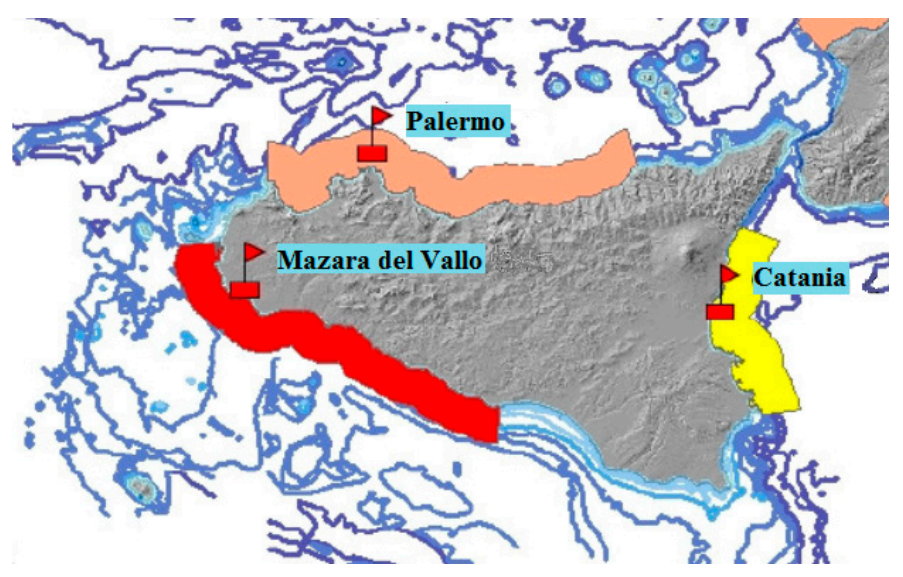

Figure 7. Measuring stations in Sicily.

In deep waters, wave power flux $\varphi_{m}$ can be obtained through the significant wave height $H_{s}$ and the energetic period $T_{e}$ by the following equation [41]:

$$
\varphi_{m}=\frac{\rho g^{2}}{64 \pi} H_{s}^{2} T_{e}
$$

in which $\rho$ is seawater density (equal to $1025 \mathrm{~kg} / \mathrm{m}^{3}$ ) and $T_{e}$ represents the energetic period (measured in seconds), equal to the peak period multiplied by a constant, which depends on the shape of wave spectrum (equal to 0.86 for a Pierson-Moskowitz spectrum and tending to 1 with the decreasing of spectral width) [42]. 
Table 2 reports the monthly average value of $H_{s}$ and $T_{e}$ for three sites: Catania, Palermo, and Mazara del Vallo. These values are obtained by processing of the data collected by RON during the period 2002-2011. The power flux of wave is evaluated, using Equation (1). The annual trends of power flux in the three different sites are reported in Figure 8.

Table 2. Monthly average wave data in Catania, Palermo, and Mazara del Vallo (2002-2011).

\begin{tabular}{ccccccccccccc}
\hline Catania & Jan. & Feb. & Mar. & Apr. & May & Jun. & Jul. & Aug. & Sep. & Oct. & Nov. & Dec. \\
\hline$H_{S}(\mathrm{~m})$ & 7.51 & 7.90 & 7.48 & 11.33 & 8.92 & 8.16 & 8.65 & 9.14 & 8.26 & 7.06 & 7.43 & 6.58 \\
$T_{e}(\mathrm{~s})$ & 0.64 & 0.80 & 0.75 & 0.65 & 0.54 & 0.40 & 0.42 & 0.44 & 0.53 & 0.59 & 0.86 & 0.74 \\
$\varphi_{m, i}(\mathrm{~kW} / \mathrm{m})$ & 1.6 & 2.5 & 2.1 & 2.4 & 1.3 & 0.6 & 0.8 & 0.9 & 1.2 & 1.2 & 2.7 & 1.8 \\
\hline Palermo & Jan. & Feb. & Mar. & Apr. & May & Jun. & Jul. & Aug. & Sep. & Oct. & Nov. & Dec. \\
\hline$H_{S}(\mathrm{~m})$ & 6.97 & 6.66 & 6.32 & 5.95 & 6.62 & 6.44 & 6.53 & 6.43 & 6.22 & 6.19 & 6.22 & 6.82 \\
$T_{e}(\mathrm{~s})$ & 1.33 & 1.26 & 0.97 & 0.81 & 0.73 & 0.55 & 0.57 & 0.63 & 0.68 & 0.82 & 0.91 & 1.33 \\
$\varphi_{m, i}(\mathrm{~kW} / \mathrm{m})$ & 6.2 & 5.3 & 3.0 & 2.0 & 1.8 & 1.0 & 1.1 & 1.3 & 1.4 & 2.1 & 2.6 & 6.0 \\
\hline Mazara del Vallo & Jan. & Feb. & Mar. & Apr. & May & Jun. & Jul. & Aug. & Sep. & Oct. & Nov. & Dec. \\
\hline$H_{S}(\mathrm{~m})$ & 7.45 & 7.44 & 7.15 & 6.95 & 6.49 & 6.02 & 6.03 & 5.72 & 5.99 & 6.05 & 6.68 & 7.13 \\
$T_{e}(\mathrm{~s})$ & 1.53 & 1.40 & 1.27 & 1.19 & 0.88 & 0.65 & 0.73 & 0.76 & 0.80 & 0.90 & 1.25 & 1.56 \\
$\varphi_{m, i}(\mathrm{~kW} / \mathrm{m})$ & 8.7 & 7.3 & 5.8 & 4.9 & 2.5 & 1.3 & 1.6 & 1.7 & 1.9 & 2.5 & 5.2 & 8.7 \\
\hline & & & & & & & & & & & &
\end{tabular}

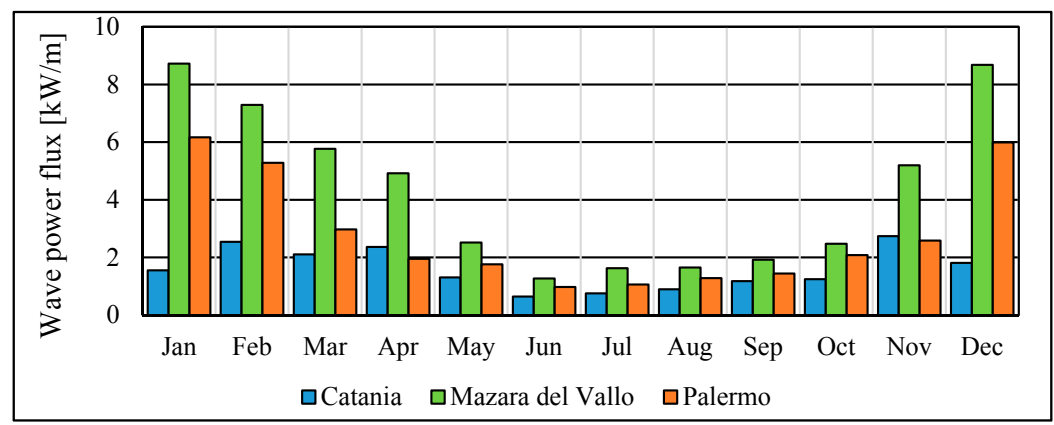

Figure 8. Monthly average wave power flux in Catania, Palermo, and Mazara del Vallo (2002-2011).

The resulting average annual power is about $1.6 \mathrm{~kW} / \mathrm{m}$ in Catania (with the main direction of sea wave from east-northeast), $2.4 \mathrm{~kW} / \mathrm{m}$ in Palermo (from west-northwest) and $4.0 \mathrm{~kW} / \mathrm{m}$ in Mazara del Vallo (from southeast and west-northwest). Additionally, in the three sites, wave power has a maximum during winter season and a minimum during summer season.

This particular trend can be useful if wave power exploitation is supported by a solar (especially photovoltaic) source. Indeed, the solar trend is opposite to the wave one, and these two trends may offset each other [43]. Figure 9 shows solar and sea-wave energy trends for a typical Mediterranean site. For this reason, we evaluated the scenario of electrical energy production from sea wave and offshore photovoltaic along the Sicilian coastline, thanks to the use of an innovative energy converter (see Figure 10), realized by DEIM of the University of Palermo.

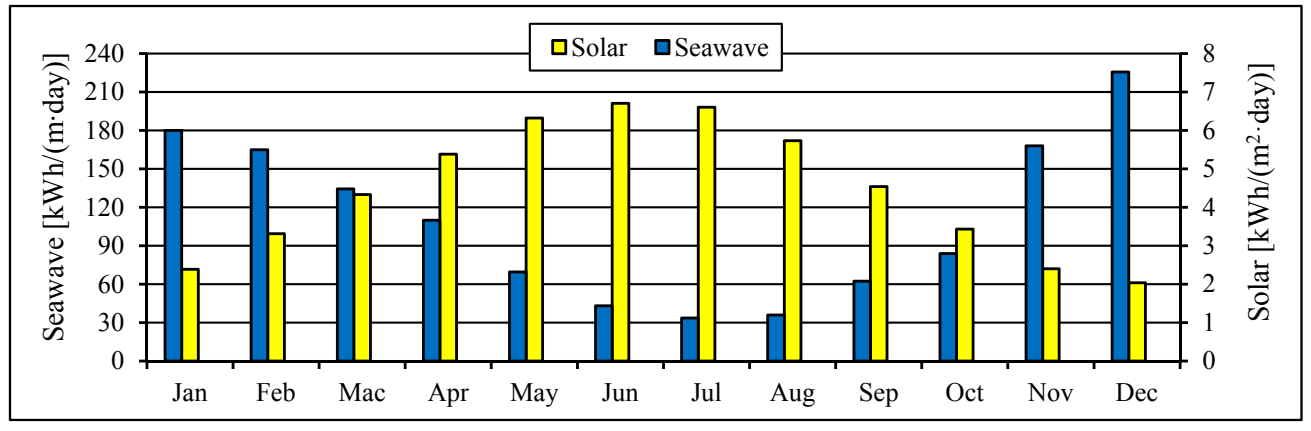

Figure 9. Comparison between solar and sea-wave trends. 


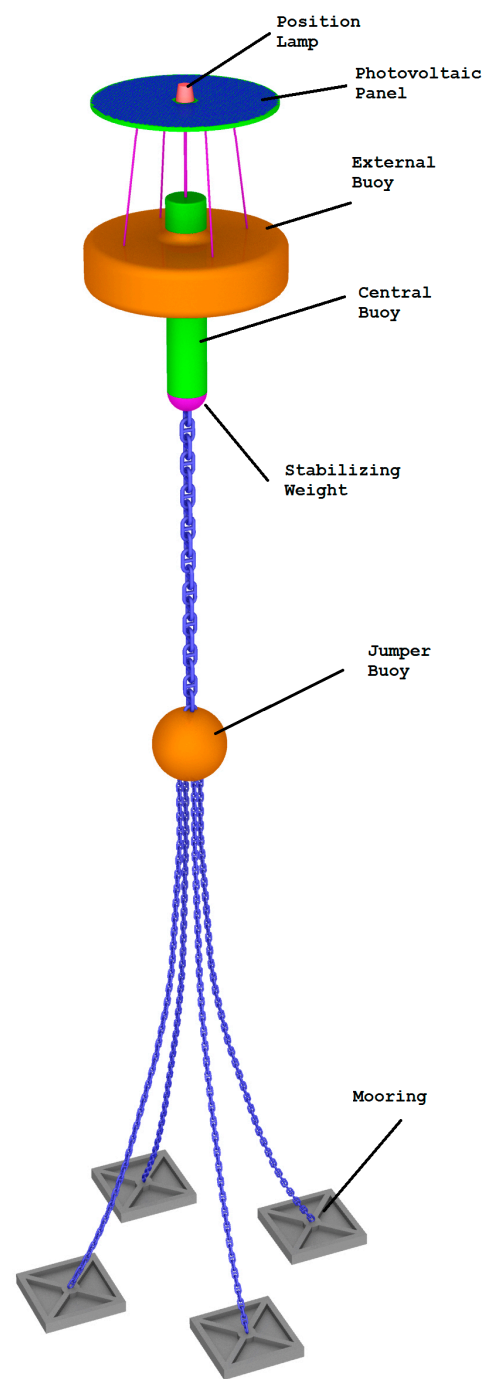

(a)

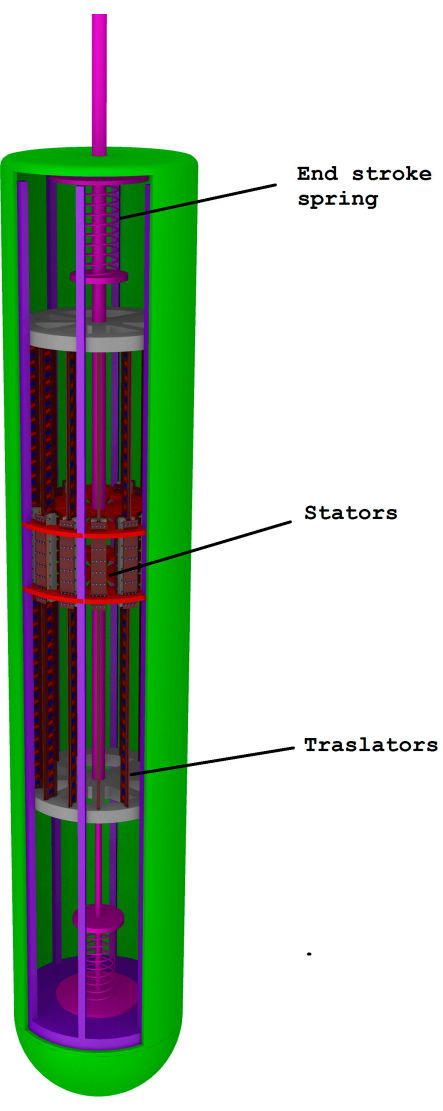

(b)

Figure 10. (a) External and (b) internal views of the Department of Energy and Information engineering and Mathematical model (DEIM) point absorber.

This point absorber converts wave energy directly into electrical, without the use of an external electrical input, intermediate devices, or polluting fluids, with high levels of efficiency [44].

DEIM converter is composed by two floating buoys. The external one intercepts the wave energy, producing a vertical motion that is transferred inside the internal buoy [45]. Sixteen linear generators are installed inside the central buoy. The magnetic flux, essential for the electrical production, is realized by permanent magnets installed in moving parts of the generators. The working stroke is about $4 \mathrm{~m}$ in order to exploit the greatest part of energetic sea states [46]. In order to limit the relative vertical motion, two springs are installed in the upper and lower parts of the central buoy, avoiding any possible damage to the conversion device, due to bad weather [47].

A photovoltaic panel is installed in the upper part of the external buoy, in order to exploit also the solar energy source.

The authors actually are investigating two different solutions to connect the solar-wave-energy farms to the grid: a decentralized approach and a partially centralized approach. In the first one, each point absorber contains an energy converter able to produce an AC electrical output that can flow into the electrical grid. In the second solution, the electrical energy produced by each point absorber is firstly converted into a DC output; the energy produced by several buoys is converted to AC and then 
transferred into the electrical grid. Several solar wave energy farms could be realized, along the Sicilian coasts, using more input points into the electrical grid. However, in this preliminary evaluation, we neglect the connection problem to the electrical grid.

The installed power $P_{W F}$ by sea wave for the three sites is evaluated by following equation:

$$
P_{W F}=P_{C, \text { Rated }} n_{C} n_{F} \varepsilon_{h y}
$$

where $P_{C, \text { Rated }}$ is the rated power of a single point absorber; $n_{C}$ is the number of devices installed in a single wave farm; and $n_{F}$ the number of wave farms.

Every solar-wave-energy farm, here proposed, will consist of 81 DEIM buoys, subdivided in three lines, according the layout reported in Figure 11. The distance among the point absorbers are selected in order to limit the hydrodynamic interferences and maximize the energy production [48].

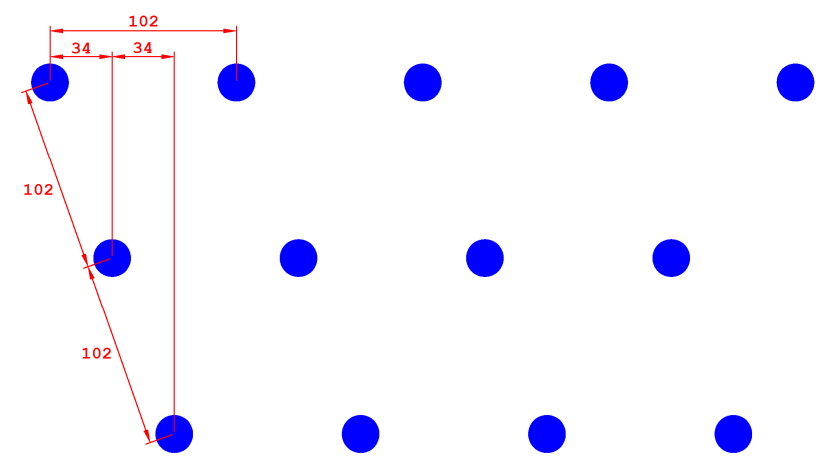

Figure 11. Wave farm layout.

In particular Figure 12 shows the hydrodynamic efficiency of a singular buoy $\varepsilon_{h y}$ as function of the normalized buoys distance, defined by equation:

$$
\lambda=\frac{2 D_{B}}{D_{C}}
$$

where $D_{C} / 2$ is the radius of the external buoy and $D_{B}$ the distance between two buoys. The hydrodynamic efficiency trend is obtained from [48], considering an elementary cell with a triangular shape.

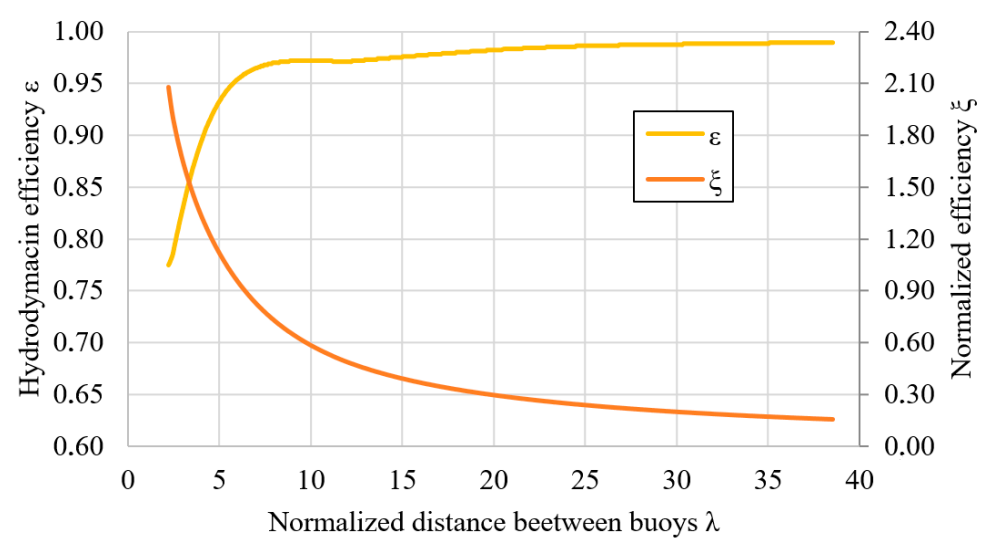

Figure 12. Hydrodynamic efficiency as function of normalized buoy distance.

Figure 12 shows also another interesting parameter: the normalized efficiency $\xi$ that represents the fraction of sea wave power flux collected by points absorbers. It is defined in the following way: 


$$
\xi=\frac{P_{W}}{L \varphi_{m}}
$$

where $P_{W}$ is the power collected by sea wave energy farm; $\varphi_{m}$ is the power flux of sea wave and $L$ is the length of wave farm.

The term $P_{W}$ is given by following equation:

$$
P_{W}=n_{C} D_{C} \varepsilon_{h y} \varphi_{m}
$$

where the terms $n_{C}, D_{C}$, and $\varepsilon_{h y}$, introduced in Equation (2), represent, respectively, the number of buoys in the wave energy farm, the diameter of the buoy, and the hydrodynamic efficiency of the point absorber. Finally, $\varphi_{m}$ is the power flux of the sea wave, defined in Equation (1).

Considering that the number of point absorbers $n_{C}$ can be expressed as product of the number of lines of point absorbers in a single wave energy farm $n_{L}$ and the number of buoys installed in a single line $n_{B L}$, Equation (4) becomes:

$$
\xi=\frac{n_{L} n_{B L} D_{C} \varepsilon_{h y} \varphi_{m}}{L \varphi_{m}}=n_{L} n_{B L} \frac{D_{C}}{L} \varepsilon_{h y}
$$

The length of wave energy farm $L$ can be expressed as:

$$
L=D_{B}\left(n_{B L}-1\right) \cong n_{B L} D_{B}
$$

where $D_{B}$ is the distance between two near buoys and $n_{B L}$ the number of buoy installed in a single line of wave energy farm. Thanks the large number of buoys, the equation can be approximate as above. Therefore, substituting the term $L$ in the Equation (7) and remembering Equation (3), finally we obtain:

$$
\xi=n_{L} n_{B L} \frac{D_{C}}{n_{B L} D_{B}} \varepsilon_{h y}=n_{L} \frac{D_{C}}{D_{B}} \varepsilon_{h y}=2 n_{L} \frac{\varepsilon_{h y}}{\lambda}
$$

As shown in Figure 12, despite that efficiency grows with increasing normalized distance, the normalized efficiency decreases inexorably. For this reason, in order to minimize the extension used by solar and wave energy farm, the normalized buoy distance is fixed to 5 . In this case, the hydrodynamic efficiency is equal to 0.93 .

In order to evaluate the electrical energy production by sea wave, a simplified approach is considered. Equation (9) estimates the electrical output for " $i$-th" month, considering the monthly average sea wave power flux $\left(\varphi_{m, i}\right)$, the external diameter of a single wave converter $\left(D_{C}\right)$, its overall efficiency $\left(\varepsilon_{C}\right)$, the hydrodynamic efficiency of solar wave energy farm $\left(\varepsilon_{h y}\right)$, the total number of installed devices $\left(n_{C} n_{F}\right)$, and, finally, the number of hours per month $\left(h_{\text {month }, i}\right)$.

$$
E_{W F, i}=\varphi_{m, i} D_{C} n_{C} n_{F} \varepsilon_{C} \varepsilon_{h y} h_{m o n t h, i}
$$

The values of monthly average power flux $\varphi_{m, i}$ are reported in Table 2. Similarly, we evaluated the installed power by solar photovoltaic and the monthly electrical output, using the following equation:

$$
\begin{gathered}
P_{P V F}=I_{P V, \text { Rated }} S_{P V} n_{C} n_{F} \varepsilon_{P V} \\
E_{P V F}=I_{\text {month }, i} S_{P V} n_{C} n_{F} \varepsilon_{P V}
\end{gathered}
$$

where $I_{P V \text {,Rated }}$ is the rated solar radiation, used to evaluate the performance of photovoltaic panels (typically $1000 \mathrm{~W} / \mathrm{m}^{2}$ ); $S_{P V}$ is the surface of solar panels; $\varepsilon_{P V}$ is the average electrical efficiency of photovoltaic panels; and $I_{m o n t h, i}$ is the monthly solar radiance, evaluated in the sites of wave energy farms. 
Table 3 reports the main parameters about the wave-solar energy farms. The data of monthly solar radiations are reported in Table 4.

We evaluated the number of solar-wave energy farms, required to cover a percentage of the electrical energy demand, measured in 2015 (22.87 TWh) [36]. Using the sea wave and solar data of the three different Sicilian sites, we proposed two different scenarios:

- CASE A-the solar-wave energy farms cover the $2 \%$ of the electrical demand;

- CASE B-the solar-wave energy farms cover the $5 \%$ of the electrical demand.

Table 3. Main parameters of sea wave-solar energy farms.

\begin{tabular}{cccc}
\hline Parameter & Symbol & Value & Unit \\
\hline Buoy diameter & $D_{C}$ & 20 & $\mathrm{~m}$ \\
Rated power of a wave converter & $P_{C, \text { Rated }}$ & 160 & $\mathrm{~kW}$ \\
Average wave converter efficiency $[21,49,50]$ & $\varepsilon_{C}$ & 50 & $\%$ \\
Average hydrodynamic efficiency of wave farm & $\varepsilon_{\text {hy }}$ & 93 & $\%$ \\
Number of buoys in wave farm & $n_{C}$ & 81 & - \\
Surface of photovoltaic panel & $S_{P V}$ & 254.5 & $\mathrm{~m}^{2}$ \\
Average photovoltaic efficiency & $\varepsilon_{P V}$ & 17 & $\%$ \\
Rated power of photovoltaic panel & $P_{P V}$, Rated & 43.3 & $\mathrm{~kW}$ \\
\hline
\end{tabular}

Table 4. Monthly solar radiation in the three sites: Catania, Palermo, and Mazara del Vallo [51].

\begin{tabular}{ccccccccccccc}
\hline $\mathbf{( k W h} / \mathbf{m}^{\mathbf{2}} \mathbf{)}$ & Jan. & Feb. & Mar. & Apr. & May & Jun. & Jul. & Aug. & Sep. & Oct. & Nov. & Dec. \\
\hline Catania & 69.2 & 97.5 & 140.0 & 150.0 & 192.5 & 204.2 & 215.0 & 189.2 & 145.0 & 112.5 & 85.0 & 62.5 \\
Palermo & 61.7 & 77.5 & 121.7 & 149.2 & 185.8 & 200.8 & 205.0 & 178.3 & 135.8 & 107.5 & 79.2 & 57.5 \\
Mazara & 84.2 & 101.7 & 135.0 & 158.3 & 198.3 & 200.0 & 205.8 & 187.5 & 156.7 & 120.8 & 87.5 & 69.2 \\
\hline
\end{tabular}

As results of this evaluations, Table 5 reports the number of wave farms required to satisfy the energy demand in the two different scenarios.

Table 5. Comparison between the two different scenarios.

\begin{tabular}{ccccccc}
\hline \multirow{2}{*}{ Parameters } & \multicolumn{3}{c}{ CASE A } & \multicolumn{3}{c}{ CASE B } \\
\cline { 2 - 7 } & Catania & Palermo & Mazara & Catania & Palermo & Mazara \\
\hline Number of farms & 5 & 7 & 7 & 14 & 16 & 18 \\
Installed Wave Power (MW) & 64.8 & 90.7 & 90.7 & 181.6 & 207.4 & 233.3 \\
Installed Solar Power (MW) & 17.5 & 24.5 & 24.5 & 49.1 & 56.1 & 63.1 \\
Annual energy by wave (MWh/y) & 52,303 & 109,746 & 182,417 & 146,450 & 250,848 & 469,072 \\
Annual energy by solar (MWh/y) & 40,778 & 38,264 & 41,821 & 93,207 & 87,461 & 95,590 \\
\hline Total annual energy (MWh/y) & \multicolumn{3}{c}{$\mathbf{4 6 5 , 3 2 9}$} \\
\hline
\end{tabular}

We evaluated also the annual trend of electrical energy production by sources and sites. In particular, Figure 13 shows the energetic trend in the scenario 2\% (Case A) and Figure 14 reports the scenario $5 \%$ (Case B). In both cases, the solar-wave energy farms show a greater production in winter than in summer, following the energy potential of sea-wave source. However, the integration of photovoltaic panel in the DEIM point absorber partially compensates for this trend. 


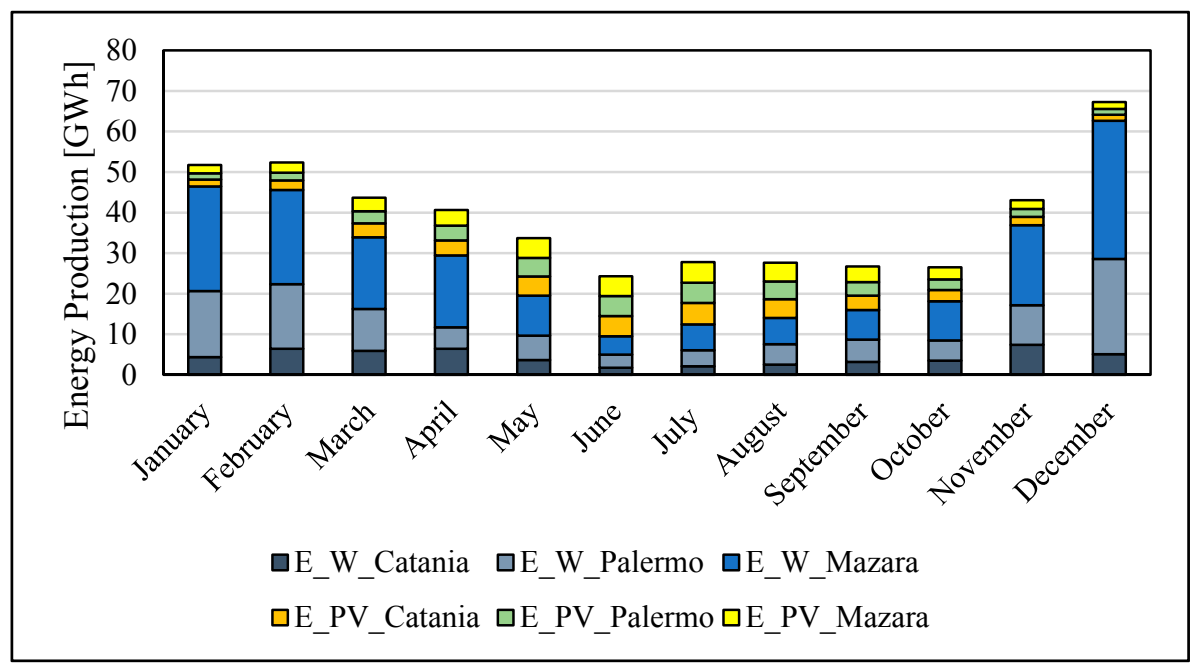

Figure 13. Annual electrical production in scenario $2 \%$ (Case A).

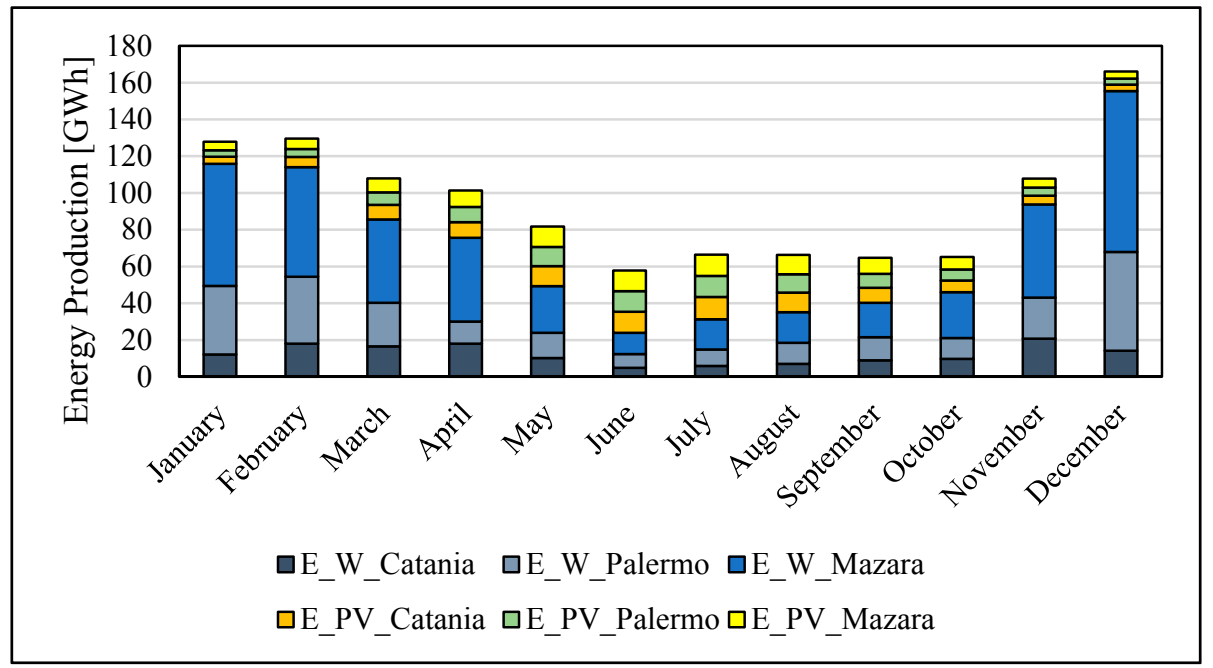

Figure 14. Annual electrical production in scenario 5\% (Case B).

Finally, considering the $\mathrm{CO}_{2}$ emissions factor is equal to $0.62 \mathrm{t} / \mathrm{MWh}$ [37], the avoided $\mathrm{CO}_{2}$ emissions are 288,504 tons/year and 708,429 tons/year, respectively, in Case A and Case B.

\section{Conclusions}

The correct use of renewable energies, especially wave energy, will contribute to the reduction of the dependence of the Sicily on exogenous fossil fuels, limiting the emissions of greenhouse gases.

The innovative WEC, proposed by Department of Energy of Palermo University, will be able to exploit hundreds of kilometers of coastline, nowadays totally unused. Thanks the integration of photovoltaic source, the DEIM point absorber can assure a more regular electrical production during the year.

The analysis of sea wave climate along the Sicilian coasts allows to identify Catania, Palermo and Mazara del Vallo as suitable sites for exploiting wave and offshore solar sources.

The authors evaluated two scenarios. In the first one, the authors considered the installation of 19 solar-wave energy farms, producing 463,531 MWh/year (which account for $2 \%$ of the electrical energy demand in 2015) and avoiding 288,504 tons/year of $\mathrm{CO}_{2}$ emissions. 
In the second scenario, the authors evaluated the installation of 48 solar-wave energy farms, producing 1,135,024 MWh/year (5\% of the electrical energy demand) and avoiding 708,429 tons/year of $\mathrm{CO}_{2}$ emissions.

Author Contributions: All authors contributed to writing the article on equal terms. All authors read and approved the final manuscript.

Conflicts of Interest: The authors declare no conflict of interest.

\section{Nomenclature}

\begin{tabular}{|c|c|}
\hline$H_{S}$ & Significant wave height $(\mathrm{m})$ \\
\hline$T_{e}$ & Energetic period (s) \\
\hline$T_{p}$ & Peak period (s) \\
\hline$\Phi_{m}$ & Average wave direction $\left(^{\circ}\right)$ \\
\hline$P$ & Power per front wave $(\mathrm{kW} / \mathrm{m})$ \\
\hline$\rho$ & Sea water density $\left(\mathrm{kg} / \mathrm{m}^{3}\right)$ \\
\hline$g$ & Gravitational acceleration $\left(\mathrm{m} / \mathrm{s}^{2}\right)$ \\
\hline$P_{\mathrm{WF}}$ & Installed power by sea wave in the site (MW) \\
\hline$P_{W}$ & Wave power collected by sea wave energy farm (MW) \\
\hline$P_{C, \text { Rated }}$ & Rated power of a single point absorber $(\mathrm{kW})$ \\
\hline$n_{C}$ & Number of point absorber per solar-wave energy farm (-) \\
\hline$n_{L}$ & Number of buoys lines in a wave energy farm (-) \\
\hline$n_{B L}$ & Number of buoy in a single lines of wave energy farm (-) \\
\hline$n_{F}$ & Number of solar-wave energy farm per site (-) \\
\hline$E_{W F, i}$ & Monthly energy production by sea wave in the site (MWh) \\
\hline$D_{C}$ & Diameter of the external buoy of point absorber $(\mathrm{m})$ \\
\hline$D_{B}$ & Distance between two buoys (m) \\
\hline$\lambda$ & Normalized distance between two buoys (-) \\
\hline$\varepsilon_{C}$ & Average energy efficiency of wave converter (\%) \\
\hline$\varepsilon_{h y}$ & Hydrodynamic energy efficiency of wave energy farm (\%) \\
\hline$\xi$ & Normalized efficiency of wave energy farm, by normalized buoys distance (-) \\
\hline$h_{\text {month }, i}$ & Number of hours per month (h/month) \\
\hline$P_{P V F}$ & Installed power by solar in the site (MW) \\
\hline$I_{P V, \text { Rated }}$ & Standard radiation $\left(\mathrm{W} / \mathrm{m}^{2}\right)$ \\
\hline$S_{P V}$ & Surface of photovoltaic panel in a single point absorber $\left(\mathrm{m}^{2}\right)$ \\
\hline$\varepsilon_{P V}$ & Average energy efficiency of photovoltaic panel (\%) \\
\hline
\end{tabular}

\section{References}

1. International Energy Agency (IEA). Energy and Climate Change; IEA: Paris, France, 2015.

2. Franzitta, V.; Curto, D.; Rao, D.; Viola, A. Hydrogen production from sea wave for alternative energy vehicles for public transport in Trapani (Italy). Energies 2016, 9, 850. [CrossRef]

3. Milone, D.; Pitruzzella, S.; Franzitta, V.; Viola, A.; Trapanese, M. Energy Savings through Integration of the Illumination Natural and Artificial, Using a System of Automatic Dimming: Case Study. Appl. Mech. Mater. 2013, 372, 253-258. [CrossRef]

4. Asdrubali, F.; Presciutti, A.; Scrucca, F. Development of a greenhouse gas accounting GIS-based tool to support local policy making-Application to an Italian municipality. Energy Policy 2013, 61, 587-594. [CrossRef]

5. Asdrubali, F.; Moncada, L.G.G.; Rotili, A. Influence of new factors on global energy prospects in the medium term: Comparison among the 2010, 2011 and 2012 editions of the IEA's World Energy Outlook reports. Econ. Policy Energy Environ. 2014, 3, 67-89. [CrossRef]

6. Franzitta, V.; Milone, A.; Milone, D.; Pitruzzella, S.; Trapanese, M.; Viola, A. A Case Study to Evaluate the Indoor Global Quality. Adv. Mater. Res. 2013, 864-867, 1054-1058. [CrossRef]

7. Hennicke, P. Scenarios for a robust policy mix: The final report of the German study commission on sustainable energy supply. Energy Policy 2004, 32, 1673-1678. [CrossRef] 
8. Tahara, K.; Kojima, T.; Inaba, A. Evaluation of $\mathrm{CO}_{2}$ payback time of power plants by LCA. Energy Convers. Manag. 1997, 38, S615-S620. [CrossRef]

9. Karekezi, S. Renewables in Africa-Meeting the energy needs of the poor. Energy Policy 2002, 30, 1059-1069. [CrossRef]

10. Barstow, S.; Mørk, G.; Mollison, D.; Cruz, J. The wave energy resource. In Ocean Wave Energy; Springer: Berlin/Heidelberg, Germany, 2008; pp. 93-132.

11. Franzitta, V.; Milone, A.; Milone, D.; Pitruzzella, S.; Trapanese, M.; Viola, A. Experimental evidence on the thermal performance of opaque surfaces in mediterranean climate. Adv. Mater. Res. 2013, 860-863, 1227-1231. [CrossRef]

12. Viola, A.; Franzitta, V.; Curto, D.; di Dio, V.; Milone, D.; Rodono, G. Environmental impact assessment (EIA) of wave energy converter (WEC). In Proceedings of the OCEANS 2015-Genova, Genova, Italy, 18-21 May 2015; pp. 1-4.

13. Rousseau, N. Oceans of Energy-European Ocean Energy Roadmap 2010-2050; European Ocean Energy Association: Brussels, Belgium, 2010.

14. Di Dio, V.; Franzitta, V.; Milone, D.; Pitruzzella, S.; Trapanese, M.; Viola, A. Design of bilateral switched reluctance linear generator to convert wave energy: Case study in Sicily. Adv. Mater. Res. 2013, 860-863, 1694-1698. [CrossRef]

15. Iuppa, C.; Cavallaro, L.; Foti, E.; Vicinanza, D. Potential wave energy production by different wave energy converters around Sicily. J. Renew. Sustain. Energy 2015, 7, 61701. [CrossRef]

16. Arena, F.; Laface, V.; Malara, G.; Romolo, A.; Viviano, A.; Fiamma, V.; Sannino, G.; Carillo, A. Wave climate analysis for the design of wave energy harvesters in the Mediterranean Sea. Renew. Energy 2015, 77, $125-141$. [CrossRef]

17. Antonio, F.D.O. Wave energy utilization: A review of the technologies. Renew. Sustain. Energy Rev. 2010, 14, 899-918.

18. De Andrés, A.D.; Guanche, R.; Weber, J.; Costello, R. Finding gaps on power production assessment on WECs: Wave definition analysis. Renew. Energy 2015, 83, 171-187. [CrossRef]

19. Arinaga, R.A.; Cheung, K.F. Atlas of global wave energy from 10 years of reanalysis and hindcast data. Renew. Energy 2012, 39, 49-64. [CrossRef]

20. Reguero, B.G.; Losada, I.J.; Méndez, F.J. A global wave power resource and its seasonal, interannual and long-term variability. Appl. Energy 2015, 148, 366-380. [CrossRef]

21. Curto, D. Ottimizzazione delle Performances Energetiche di un Innovativo Generatore di Energia Elettrica da Moto Ondoso; Gruppo Editoriale L'Espresso: Rome, Italy, 2015.

22. Bozzi, S.; Archetti, R.; Passoni, G. Wave electricity production in Italian offshore: A preliminary investigation. Renew. Energy 2014, 62, 407-416. [CrossRef]

23. Lionello, P.; Sanna, A. Mediterranean wave climate variability and its links with NAO and Indian Monsoon. Clim. Dyn. 2005, 25, 611-623. [CrossRef]

24. Colucci, A.; Boscaino, V.; Cipriani, G.; Curto, D.; di Dio, V.; Franzitta, V.; Trapanese, M.; Viola, A. An inertial system for the production of electricity and hydrogen from sea wave energy. In Proceedings of the OCEANS 2015-MTS/IEEE Washington, Ocean, Washington, DC, USA, 19-22 October 2015; pp. 1-10.

25. Iglesias, G.; Carballo, R. Wave energy and nearshore hot spots: The case of the SE Bay of Biscay. Renew. Energy 2010, 35, 2490-2500. [CrossRef]

26. Guillou, N.; Chapalain, G. Numerical modelling of nearshore wave energy resource in the Sea of Iroise. Renew. Energy 2015, 83, 942-953. [CrossRef]

27. Vicinanza, D.; Cappietti, L.; Ferrante, V.; Contestabile, P. Estimation of the wave energy in the Italian offshore. J. Coast. Res. 2011, 64, 613-617.

28. Vicinanza, D.; Cappietti, L.; Contestabile, P. Assessment of wave energy around Italy. In Proceedings of the 8th European Wave and Tidal Energy Conference, Uppsala, Sweden, 7-10 September 2009; pp. 256-262.

29. Monteforte, M.; Re, C.L.; Ferreri, G.B. Wave energy assessment in Sicily (Italy). Renew. Energy 2015, 78, 276-287. [CrossRef]

30. Franzitta, V.; Curto, D.; Milone, D.; Viola, A. The Desalination process driven by wave energy: A challenge for the future. Energies 2016, 9, 1032. [CrossRef]

31. Liberti, L.; Carillo, A.; Sannino, G. Wave energy resource assessment in the Mediterranean, the Italian perspective. Renew. Energy 2013, 50, 938-949. [CrossRef] 
32. Vicinanza, D.; Contestabile, P.; Ferrante, V. Wave energy potential in the north-west of Sardinia (Italy). Renew. Energy 2013, 50, 506-521. [CrossRef]

33. Besio, G.; Mentaschi, L.; Mazzino, A. Wave energy resource assessment in the Mediterranean Sea on the basis of a 35-year hindcast. Energy 2016, 94, 50-63. [CrossRef]

34. Terna S.p.A. Dati Storici. 2013. Available online: https://www.terna.it/it-it/sistemaelettrico/ statisticheeprevisioni/datistorici.aspx (accessed on 14 March 2017).

35. Moreci, E.; Ciulla, G.; Brano, V.L. The Energy System of Sicilian Region, Italy: 2014 situation and evolutionary trends. In Proceedings of the 2015 International Conference on Renewable Energy Research and Applications (ICRERA), Palermo, Italy, 22-25 November 2015; Volume 5, pp. 1348-1353.

36. Dipartimento dell'Energia-Regione Sicilia. Rapporto Energia 2015 Monitoraggio Sull'energia in Sicilia; Regione Sicilia: Palermo, Italy, 2015.

37. Mancuso, E. La Contabilità Delle Emissioni dei Gas ad Effetto Serra a Livello Locale: Le Emissioni Regionali di $\mathrm{CO}_{2}$; Energia, Ambiente e Innovazione (EAI): Rome, Italy, 2011.

38. Autorità per L'energia Elettrica il Gas e il Sistema Idrico (AEEG). Delibera EEN 3/08-Aggiornamento del Fattore di Conversione dei $\mathrm{kWh}$ in Tonnellate Equivalenti di Petrolio Connesso al Meccanismo dei Titoli di Efficienza Energetica; AEEG: Rome, Italy, 2008.

39. Dipartimento di Ricerche Energetiche ed Ambientali (DREAM)-Università degli Studi di Palermo. Piano Energetico Ambientale Regionale Della Regione Siciliana; Regione Sicilia: Palermo, Italy, 2007.

40. Iuppa, C.; Cavallaro, L.; Vicinanza, D.; Foti, E. Investigation of suitable sites for wave energy converters around Sicily (Italy). Ocean Sci. Discuss. 2015, 12, 315-354. [CrossRef]

41. Viola, A.; Franzitta, V.; Trapanese, M.; Curto, D. Nexus water \& energy: A case study of wave energy converters (WECs) to desalination applications in Sicily. Int. J. Heat Technol. 2016, 34, S379-S386.

42. Cornett, A.M. A global wave energy resource assessment. In Proceedings of the Eighteenth International Offshore and Polar Engineering Conference, Vancouver, BC, Canada, 6-11 July 2008.

43. Franzitta, V.; Curto, D.; Milone, D.; Rao, D. Assessment of renewable sources for the energy consumption in Malta in the Mediterranean Sea. Energies 2016, 9, 1034. [CrossRef]

44. Franzitta, V.; Trapanese, M.; Giaconia, C.; Ferrara, P.; Viola, A. Design and experimental test of a low costweather buoy. In Proceedings of the 2013 MTS/IEEE OCEANS-Bergen, Bergen, Norway, 10-14 June 2013; pp. 1-5.

45. Trapanese, M.; Franzitta, V.; Viola, A. A dynamic model for hysteresis in magnetostrictive devices. J. Appl. Phys. 2014, 115, 1-4. [CrossRef]

46. Franzitta, V.; Di Dio, V.; Viola, A.; Giaconia, C.; Ferrara, P.; Trapanese, M. Experimental results of a low cost weather buoy. In Proceedings of the 2013 OCEANS, San Diego, CA, USA, 23-27 September 2013; pp. 1-5.

47. Franzitta, V.; Viola, A.; Trapanese, M. Design of a transverse flux machine for power generation from seawaves. J. Appl. Phys. 2014, 115, 17E712. [CrossRef]

48. Balitsky, P.; Bacelli, G.; Ringwood, J.V. Control-influenced layout optimization of arrays of wave energy converters. In Proceedings of the ASME 2014 33rd International Conference on Ocean, Offshore and Arctic Engineering, San Francisco, CA, USA, 8-13 June 2014; p. V09BT09A022.

49. Franzitta, V.; Curto, D.; Rao, D. Energetic sustainability using renewable energies in the Mediterranean Sea. Sustainability 2016, 8, 1164. [CrossRef]

50. Franzitta, V.; Curto, D. Sustainability of the renewable energy extraction close to the Mediterranean Islands. Energies 2017, 10, 283. [CrossRef]

51. Ente Italiano di Normazione (UNI). Norma UNI 10349 Parte 1-Dati Climatici Ed. 2016; Ente Italiano di Normazione: Rome, Italy, 2016.

(c) 2017 by the authors. Licensee MDPI, Basel, Switzerland. This article is an open access article distributed under the terms and conditions of the Creative Commons Attribution (CC BY) license (http:/ / creativecommons.org/licenses/by/4.0/). 